\title{
THE ASSESSMENT OF COMPLIANCE OF THE INPATIENT STAGE PHARMACOTHERAPY WHEN TREATING RHEUMATOID ARTHRITIS WITH PROVISIONS OF INDUSTRY STANDARDS
}

\author{
O.M.Kyrychenko, Ye.I.Hyzhka
}

National University of Pharmacy

Key words: rheumatoid arthritis; inpatient treatment stage; frequency analysis; gastroprotective drug prevention

\begin{abstract}
The ongoing monitoring of the inpatient stage of treatment is the necessary condition for improving the quality of pharmacotherapy of such costly diseases as rheumatoid arthritis (RA) and optimizing the costs for its implementation. According to the data of 100 case histories of patients with RA the use of glucocorticoids (GCS), non-steroidal anti-inflammatory drugs (NSAIDs) and gastroprotective drug prevention of complications associated with their use at the inpatient stage of treatment has been analyzed, and compliance of prescriptions with the provisions of the updated national unified clinical protocol of 2014 (UCPMC RA), as well as the recommendations of the European League Against Rheumatism (EULAR) in taking GCs and NSAIDs for rheumatoid diseases has been identified. It was formulated that GCs for systemic use and NSAIDs were prescribed according to the regimens specified in UCPMC RA and in compliance with the algorithm of the rational choice of NSAIDs for RA. It was determined that for the levels of prescriptions of GCs and NSAIDs set the gastroprotective drug prevention of complications associated with their use in the rheumatology department was carried out properly and according to the recommendations of UCPMC RA and EULAR. A high level of compliance by practitioners of a healthcare institution with the provisions of the current UCPMC RA has been determined, and it will allow both preventing in advance possible undesired effects of using GCs and NSAIDs and reducing the costs of their correction.
\end{abstract}

$\mathrm{T}$ he ongoing monitoring of drug therapy at the inpatient stage of treatment and its compliance with the provisions of the industry standards of healthcare are significant steps to improve the quality of medical care and optimize the costs for its implementation. This analysis is especially important for ICD diseases with costly treatment and those diseases that affect people of the working age. Rheumatoid arthritis (RA) is one of these diseases, its peak incidence occurs in women aged 41 and men aged 45, i.e. the working age. According to epidemiological data approximately $20-30 \%$ of patients lose efficiency during the first 2-3 years of the disease, and up to $85 \%$-within the following 8-11 years [4, 5]. According to estimates of most countries it is indirect costs (in particular those that are due to premature mortality, deterioration of the life quality, payments on sick leaves and disability) that represent a significant share in the expenditure pattern of RA $[7,8]$.
The updated national unified clinical protocol of medical care of 2014 (UCPMC RA) defines two areas of drug therapy for RA: 1) modification of the disease process aimed at slowing or stopping the radiographic progression, which is closely correlated with the expression of functional disorders; 2 ) reduction of symptoms with priority of pain relief in RA patients [5]. Glucocorticoids (GCs), non-steroidal anti-inflammatory drugs (NSAIDs) and analgesics are prescribed to reduce quickly exacerbation and suppression of the pain syndrome intensity in joints.

When using GCs the necessity for mandatory risk assessment of side effects development associated with their administration, and determination of the presence of comorbidities in the patient are specified in the evidence-based recommendations of the European League Against Rheumatism (EULAR). Attention is paid to the presence of the parallel treatment of NSAIDs, hypertension, gastric ulcer and duodenal ulcer, diabe- tes, chronic infections, bone fractures, etc. It is recommended to prescribe gastroprotective drugs (proton pump inhibitors (PPIs) or Misoprostol) to patients who are treated with GCs and concomitant NSAIDs, or as an alternative patients can be transferred to a selective inhibitor of cyclooxygenase-2 (the I-st level of evidence, with 95\% CI: 91 (84-98), which is not characterized by gastrotoxicity [6].

The algorithm of the rational choice of a particular NSAID and the concomitant therapy (PPIs, acetylsalicylic acid) is shown in detail in UCPMC RA (2014). It is noted that selection of both classical NSAIDs, and COX-2 specific inhibitors without/or with PPIs depends on the presence and the number of risk factors in the GIT (previous events in the upper sections of the GIT, the age $\geq 65$ years old, chronic administration of NSAIDs, concomitant use of GCs or aspirin) and in the CVS. In UCPMC RA there are also cases when prescription of any NSAIDs should be avoided [5].

The aim of our study was to analyze the use of GCs, NSAIDs and 
gastroprotective drug prevention of complications associated with the use of GCs, NSAIDs in patients with RA at the inpatient stage of treatment and to determine whether prescriptions are complied with the recommendations of EULAR and UCPMC RA of 2014.

\section{Materials and Methods}

The objects of the study were case histories of patients with RA who were treated in the rheumatology department of one of the regional clinical hospital. The following methods of research were used: a retrospective analysis of case histories and drug administration records of patients with RA; a supplementary method of clinical and economic analysis frequency analysis, which at the inpatient treatment stage determines the proportion of patients who this or that pharmacotherapeutic group and/or drug (drugs) were prescribed to [6]; analytical (analysis of the EULAR recommendations for treating RA and the RA National Clinical Guidelines of 2014 (UCPMC RA)).

\section{Results and Discussion}

100 Case histories of patients with RA were analyzed, and 21 patients were diagnosed with the first stage of the disease (the process activity $\mathrm{DAS}_{28}<3.2$ ), 67 and 12 patients - with the second stage $\left(\mathrm{DAS}_{28} 3.2-5.1\right)$ and the third stage (DAS ${ }_{28}>5.1$ ), respectively. Concomitant diseases of the endocrine, cardiovascular, musculoskeletal and nervous systems were observed in the study range of case histories. The largest group (35.9\% of all comorbidities) consisted of pathologies of the musculoskeletal system, namely spondylarthrosis, primary and secondary osteoarthritis, generalized osteoporosis, etc. The second place among all the comorbidities in RA patients is taken by diseases of the endocrine system, among which the most patients $(34.6 \%)$ have a diagnosis of "glucocorticoid dependence."

\section{Frequency of prescriptions (\%) of drugs of groups A02, H02 and M01 to patients with rheumatoid arthritis according to the data of the drug administration records taking into account the stages of the disease}

\begin{tabular}{|l|c|c|c|}
\hline \multirow{2}{*}{\multicolumn{1}{|c|}{ ATC group }} & \multicolumn{3}{c|}{ Frequency of prescriptions (in \%) } \\
\cline { 2 - 4 } & \multicolumn{3}{|c|}{ Stages of RA } \\
\cline { 2 - 4 } & I stage & II stage & III stage \\
\hline $\begin{array}{l}\text { A02 - drugs for the treatment } \\
\text { of acid-related diseases }\end{array}$ & $71.42 \%$ & $91.04 \%$ & $91.66 \%$ \\
\hline H02 - GCs for systemic use & $123.81 \%$ & $137.31 \%$ & $183.34 \%$ \\
\hline $\begin{array}{l}\text { M01 - anti-inflammatory } \\
\text { antirheumatic drugs }\end{array}$ & $100 \%$ & $88.06 \%$ & $100 \%$ \\
\hline
\end{tabular}

The frequency analysis conducted by these drug administration records made it possible to determine the proportion of patients who GCs, NSAIDs and PPIs were prescribed to.

According to the data of the frequency analysis at the inpatient stage of treatment GCs were prescribed to the patients with RA diagnosed with the I, II and III stage of the disease in $123.81 \%$, $137.31 \%$ and $183.34 \%$ cases, respectively (Table). That is for the part of the patients various GC treatment regimens were used simultaneously or one after another: pulse therapy, combination background therapy (methotrexate + GCs orally) and local therapy. For rapid inhibition of the inflammatory activity and induction of remission in $28 \%$ of the RA patients with the stage I, in $59.7 \%$ and $100 \%$ of the patients with the stage II and III, respectively, the GC pulse therapy was used. It is believed that in contrast to the regular hormone therapy the GC pulse therapy causes no persistent side effects, no hormonal dependence and does not inhibit the adrenocortical function [1]. In practice, various regimens of the pulse therapy are used, and among them the methylprednisolone therapy (1.000 mg intravenously) has proven its efficacy in many studies [8]. Simultaneously with the aim of stabilizing the remission the second line of therapy - methotrexate + GCs (orally) - was prescribed. GCs were also used for topical application (intra-articular) as the additional method of eliminating RA complications.

The NSAIDs therapy was received by $100 \%$ of patients with the stage I of RA. Only parenteral forms of NSAIDs were prescribed to these patients; among them $57.14 \%$ were non-selective (n-NSAIDs), namely - diclofenac, and 42.86\% moderately selective in relation to COX-2 (ms-NSAIDs) - meloxicam. NSAIDs were prescribed to the majority $(71.42 \%)$ of patients with the stage I of RA in combination with PPIs (pantoprazole and omeprazole). Taking into account the algorithm of the rational choice of NSAIDs presented in UCPMC RA, IPPs were not probably prescribed to other patients in the absence of risk factors in GIT and CVS, or vice versa - when combining of the high CVS and GIT risks. The presence of the own class-specific side effects in PPIs (the increased risk of intestinal infections, pneumonia, progression of osteoporosis, etc.) is also considered to be a contraindication for their use [2].

The proportion of patients with RA of II and III stage who received NSAIDs was $88.06 \%$ and $100 \%$, respectively. Among parenteral forms of NSAIDs, ms-NSAIDs and n-NSAIDs were used in $75 \%$ and 
85.7\% cases, respectively. Among oral dosage forms ms-NSAIDs (Nimesulide) and selective NSAIDs (Celecoxib) were used in 100\% of cases.

In the above levels of prescriptions of NSAIDs and GCs in patients with stages II and III of RA the drug gastroprotective therapy with PPIs (pantoprazole, omeprazole, esomeprazole) was used in $91.04 \%$ and $91.66 \%$ cases, respectively.

All NSAIDs prescribed in the healthcare institution, except for Nimesulide, are specified in the recommendations of UCPMC RA concerning the balanced use of NSAIDs for rheumatic diseases. It should be noted that Nimesulide is presented in National Drug Formularies of the $5^{\text {th }}$ and $7^{\text {th }}$ editions (2013-2015) with the recommendations for the symptomatic treatment of the pain syndrome in case of RA, osteoarthritis and other diseases of the musculoskeletal system. It is considered that tolerability of Nimesulide is better compared to n-NSAIDs. However, as to development of GIT bleeding and perforations, Nimesulide has no advantages over traditional NSAIDs [2].
Thus, the data of the structure of NSAIDs prescriptions analyzed indicate a balanced approach of medical practitioners to their choice and compliance with the provisions of UCPMC RA (2014) for the rational choice of NSAIDs for rheumatic diseases, as well as the recommendations of the National Drug Formulary.

Taking into account the amount of the PPIs administration this group of drugs was probably prescribed in the presence of clear indications to their use. One should be also considered the class-specific undesired side effects of these drugs (progression of osteoporosis, increased risk of intestinal infections, etc.), as well as the fact that $24 \%$ of patients were diagnosed with glucocorticoid-induced osteoporosis together with RA, and 54\% - with hormonal dependence.

\section{CONCLUSIONS}

According to the data of 100 case histories of patients with RA the analysis of the use of GCs, NSAIDs and the gastroprotective drug prevention of complications associated with their use has identified compliance of prescriptions with the provisions of the upda- ted national unified clinical protocol of 2014, as well as the EULAR in taking GCs and NSAIDs in RA. These prescriptions were conducted taking into account risk factors for development of side effects associated with administration of GCs and NSAIDs, the presence of concomitant diseases in patients, as well as according to the regimens specified in UCPMC RA and in compliance with the algorithm of the rational choice of NSAIDs for RA.

It has been determined that for the levels of prescriptions of GCs and NSAIDs set the gastroprotective drug prevention of complications associated with their use in the rheumatology department was carried out in compliance with the provisions of UCPMC RA and EULAR.

The results obtained indicate a high level of compliance by practitioners of a healthcare institution with the recommendations of the current clinical protocol of treatment of rheumatoid arthritis, and it will allow both preventing in advance possible undesired effects of using GCs and NSAIDs and reducing the costs of their correction.

\section{REFERENCES}

1. Каратеев Д.Е. // Лечащий врач. - 2002. - №7. [Електронний ресурс] Режим доступу: httр:// www.lvrach.ru /2007/02/4534789

2. Каратеев А.Е., Насонов Е.Л., Яхно Н.Н. и др. // Современная ревматол. - 2015. - №1. - С. 4-24.

3. Морозов А.М., Яковлєва Л.В., Бездітко Н.В. та ін. Методичні рекомендації з оцінки клінічної та економічної доцільності використання лікарських засобів улікувально-профілактичному закладі (супровід формулярної системи). - Х.: НФаУ, 2012. - 59 с.

4. Нейко Є.М., Яцишин Р.І., Штефюк О.В. // Укр. ревматол. журн. - 2009. - №2 (36). - C. 35-39.

5. Уніфікований клінічний протокол первинної, вторинної (спеціалізованої), третинної (високоспеціалізованої) медичної допомоги та медичної реабілітації. Ревматоїдний артрит / Під ред. М.К.Хобзей, О.Б.Яременко, О.П.Борткевич та ін. / МОЗ України, ДП «Державний експертний центр МОЗ України». - К., 2014. -42 c.

6. Hoes J.N., Jacobs J.W.G., Boers M. et al. // Укр. ревматол. журн. - 2008. - №3 (33). - C. 4-13.

7. Huscher D., Mittendorf T., von Hinüber U. // Ann. Rheumatic Dis. - 2015. - Vol. 74. - P. 738-745.

8. Raciborski F., Kłak A., Kwiatkowska B. // Reumatol. - 2015. - Vol. 53 (5). - P. 268-275.

9. Van der Goes M.C., Jacobs J.W., Bijlsma J.W. // Arthritis Res. \& Therapy. - 2014. - Vol. 16 (Suppl 2). - S2 Режим доступy: http://arthritis-research.com/content/16/S2/S2 


\section{ОЦІНКА ВІДПОВІДНОСТІ ФАРМАКОТЕРАПІЇ СТАЦІОНАРНОГО ЕТАПУ ЛІКУВАННЯ РЕВМАТОЇДНОГО АРТРИТУ ПОЛОЖЕННЯМ ГАЛУЗЕВИХ СТАНДАРТІВ}

О.М.Кириченко, Є.І.Хижка

Національний фармацевтичний університет

Ключові слова: ревматоїдний артрит; стаціонарний етап лікування; частотний аналіз; гастропротекторна медикаментозна профілактика

Постійний моніторинг стаціонарного етапу лікування $\epsilon$ необхідним підходом до підвищення якості фармакотерапії та оптимізації витрат на їі реалізацію таких високовартісних у лікуванні захворювань як ревматоїдний артрит (РА). За даними 100 історій хвороб пацієнтів з РА проведено аналіз використання глюкокортикоїдів (ГК), нестероїдних протизапальних та протиревматичних засобів (НППЗ) та гастропротекторної медикаментозної профілактики ускладнень, пов'язаних із їх застосуванням на стаціонарному етапі лікування та визначено відповідність призначень положенням оновленого національного клінічного протоколу 2014 р. (УКПМД PA) та рекомендаціям Європейської антиревматичної ліги (EULAR) з використання ГК та НППЗ при ревматоїдних захворюваннях. Сформульовано, що призначення ГК для системного застосування та НППз проводилося за зазначеними в УКПМД РА схемами та з дотриманням алгоритму раціонального вибору НППЗ при РА. Визначено, що при встановлених рівнях призначень ГК та НППЗ гастропротекторна медикаментозна профілактика ускладнень, пов'язаних із їх вживанням у ревматологічному відділенні, виконувалась належним чином та за рекомендаціями УКПМД РA та EULAR. Встановлено високий ступінь дотримання практикуючими лікарями закладу охорони здоров'я положень діючого УКПМД РА, що дозволить як завчасно попереджати можливі небажані наслідки використання ГК та НППЗ, так і зменшувати витрати на їх корекцію.

\section{ОЦЕНКА СООТВЕТСТВИЯ ФАРМАКОТЕРАПИИ СТАЦИОНАРНОГО ЭТАПА ЛЕЧЕНИЯ РЕВМАТОИДНОГО АРТРИТА ПОЛОЖЕНИЯМ ОТРАСЛЕВЫХ СТАНДАРТОВ}

\section{О.Н.Кириченко, Е.И.Хижка}

Национальный фармацевтический университет

Ключевые слова: ревматоидный артрит; стационарный этап лечения; частотный анализ; гастропротекторная медикаментозная профилактика

Постоянный мониторинг стационарного этапа лечения является необходимым условием повышения качества фармакотерапии и оптимизации затрат на ее реализацию таких дорогостоящих в лечении заболеваний как ревматоидный артрит (РА). По данным 100 историй болезни пациентов с РА проведен анализ использования глюкокортикоидов (ГК), нестероидных противовоспалительных средств (НПВС) и гастропротекторной медикаментозной профилактики осложнений, связанных с их применением на стационарном этапе лечения и определены соответствия назначений положениям обновленного национального клинического протокола 2014 (УКПМП РА) и рекомендациям Европейской антиревматической лиги (EULAR) по использованию ГК и НПВС при ревматоидных заболеваниях. Сформулировано, что назначение ГК для системного применения и НПВС проводилось по указанным в УКПМП РА схемам и с соблюдением алгоритма рационального выбора НПВС при РА. Определено, что при установленных уровнях назначений ГК и НПВС гастропротекторная медикаментозная профилактика осложнений, связанных с их употреблением в ревматологическом отделении, выполнялась должным образом и по рекомендациям УКПМП РA U EULAR. Установлен высокий уровень соблюдения практикующими врачами учреждения здравоохранения положений действующего УКПМП РА, что позволит как заблаговременно предупреждать возможные нежелательные последствия использования ГК и НПВС, так и уменьшать затраты на их коррекцию.

Address for correspondence:

4, Valentynivska str., Kharkiv, 61168, Ukraine.

Tel. (572) 65-88-95. E-mail: ph-econom@nuph.edu.ua.

National University of Pharmacy 